\title{
ACTANTS OF THE THEMATIC GROUP OF PREDICATES \\ OF IRRATIONAL STATE ACQUISITION IN THE UKRAINIAN, ENGLISH AND GERMAN LANGUAGES
}

\author{
Anastasiia Kinashchuk \\ Postgraduate Student, Rivne State University for the Humanities, Ukraine \\ e-mail: nastia.kinash@gmail.com,orcid.org/0000-0002-5675-240X
}

\section{Summary}

The study presents predicate-actant modeling as one of the means to research the semantic structure of irrational vocabulary in the Ukrainian, English and German languages. The author singles out the group of predicates to denote the process of irrational state acquisition in chosen languages. The research specifies the notion of predicate and actant in the aspect of functional syntax. The paper reveals semantic roles of participants of irrational situation. The study researches actants of the mentioned thematic group of predicates according to their syntactical expression, communicative rank and taxonomic class in semantic structure of irrational vocabulary in each of the compared languages. The author states predicate-actant relations for mentioned thematic group of predicates within the irrational situation. The paper defines following research of semantic structures of irrational vocabulary in comparative aspects.

Keywords: predicate-actant relations, predicate-actant modeling, functional syntax, semantic role, syntactical role, syntactical expression, communicative rank, taxonomic class.

\section{DOI: https://doi.org/10.23856/4508}

\section{Inroduction}

Nowadays functional syntax is presented as a separate linguistic direction focused on the researching semantic roles and elements of the situation in a semantic structure. Foreign (A. Mustaioki, Yu. Apresian, O. Paducheva) and Ukrainian (O. Demenchuk, H. Valihura) linguists research functional syntax in their papers. Involving the material of related and unrelated languages these papers aim not only to define predicate-actant relations between the participants and elements of some situation but also to present specific features of human's cognitive activity. The importance of the research deals with anthropocentric trend of linguistic studies of related and unrelated languages in modern linguistics.

\section{Materials and methods}

The authors' findings within functional syntax reveal high interest of the researchers in a sentence semantic structure studying to describe syntactical and super-syntactical constituents (I. Susov), examine methodological fundamentals of predicate typology development (L. Krasnova), outline up-to-date approach to the analysis of semantic structure of polysemantic word (A. Shumeikina), present correlations of grammatical and semantic characteristics of a sentence (N. Shvedova), explore syntactical means of real situation representation (Z. Sabitova) and others.

Along with that the researchers of functional syntax study specific lexical and semantic groups of words in different languages to study semantic models of the sentences with predicates 
of creation in the Russian languages (N. Ruzhentseva), semantic and syntactical structure of sentences with illocutionary predicates in the Ukrainian language (H. Valigura), actant-predicate relations of telescope language units basing on the French language (N. Smirnova, D. Spiridonov), development of semantic and syntactical typology of knowledge predicates in the English, Russian and Ukrainian languages (O. Bohovyk) and others. The authors' findings of this direction present the importance of papers in functional syntax not only with the aim to research predicate-actant models inside the language but in the comparative aspect as well.

The study presents comparative actants analysis of predicates of thematic group to define the process of irrational state acquisition. This group demonstrates the process of gradual acquisition ("feeling") of some information in the irrational way. In the Ukrainian, English and German languages the subject of the study is presented with such predicates as, cf. ukr. передчувати, пречувати, прочувати, прочуватися, передчуватися, угадувати; eng. feel, intuit, predict, anticipate, presage, sense; ger. voraussehen, orakeln, prognostizieren, wittern, spüren, verspüren.

The aim of the study is to characterize the actants of thematic group of predicates to define "the process of irrational state acquisition" in the Ukrainian, English and German languages.

The aim is achieved by the solution of such tasks as:

- to specify the notion of the predicate and actant in the aspect of functional syntax;

- to characterize actants of researched thematic group of predicates in the comparative aspect;

- to describe specific features of predicate-actant relations of irrational predicates in researched languages;

- to identify the prospects of the following research of irrational vocabulary.

The material of the research is presented with 31 verbs (12 from the Ukrainian language, 14 from the English language, 5 from the German language) that belong to the semantic class of irrational vocabulary and were selected by continuous sampling method.

It was chosen descriptive, contrastive and modeling methods as the basic ones in the research. Descriptive method gives a possibility to systematize and generalize collected information and factual material. With the help of contrastive method it was analyzed special features of presentation of predicate-actant relations in the Ukrainian, English and German languages. To develop predicate-actant models it was used the modeling method. This sytem of methods provide conclusions validity and objective evidence.

\section{Results}

A. Mustaioki states that the description of model of functional syntax bases on semantic structures that present the state of affairs and comments of that one who speaks about this state of affairs (Mustaioki, 2006: 412). The central element of the core semantic structure is the core that consists of predicate and actants. The author interprets the notion of predicate as a logic constituent of the utterance that concerns with the meaning of this utterance and defines the relation of the subject with other constituents of semantic structure. The analysis of predicates seems to be impossible without the analysis of the accompanying actants. The author interprets the actant as a situation participant that fills the valence of predicate according to some semantic role and has the relations appropriate to this predicate. The study presents such basic participants of irrational situation as Experiencer, Stimulus and Content. Experiencer is considered as a subject of irrational state that "feels" irrationality in some demonstrations (guess, impulse, 
instinct, intuition): cf. ukr. Високо-високо в глибинах блакиті викупуються реактивні, небо від них аж дзвенить, і хоч сония ще й нема, щзе десь воно за вигином планети, а из хлопці й дівчата вже передчувають його, вже бачать його вгорі, у вранішнім першім промінні, щзо барвить білий летючий метал (KUM); eng. Ludens, arriving, would have to intuit what was required (BNC); ger. Hier witterten die Aufklärer verständlicherweise höchste Gefahr $(D W D S)$ ). Stimulus participant may be presented with different types of intellectual objects that influence on the subject of irrational situation, sense organs, and mind: cf. ukr. Які там щзе $\epsilon$ на світі люди, щуо можуть передчувати мою появу там чи там? (KUM); eng. Cап уои guess what this data set is? (Translate.ru); ger. Möchte jemand raten, welche das ist? (Translate.ru). The participant Content is interpreted as some information (message) that is perceived (felt, comprehended, guessed) by Experiencer of the situation that processes this information in some way: ukr. Підсвідомо я здогадувався, що ие побачення затіяно, аби вивести мене 3 рівноваги (CUM); eng. Can you guess what this data set is? (Translate.ru); ger. Möchte jemand raten, welche das ist? (Translate.ru). The study characterizes each of the semantic roles of the situation giving appropriate examples.

In the situation of "the process of irrational state acquisition" Experiencer occupies the position of the subject: ukr. Ангеліна ніби передчувала : тільки-но вона дала лад своїи скуйовдженій зачісиі, як розчинилися двері і на порозі став Платон (KUM). This actant may be syntactically expressed with:

- singular or plural noun: ukr. Поет бачив завтрашній день без кріпаччини, передчував «сім'ю вольну, нову», був ясновидцем відродження, предтечею грядущої револючійної бурі (CUM); Сусіди давно передчували недобре (Breaking nеws);

- personal pronoun: ukr. Били копитами й шарпалися, пряли вухами, чуючи тими вухами рев літаків $і$ не дуже-то далекі вибухи бомб, нервувалися, а деякі без причин жалібно іржали, позираючи навколо, близьку смерть (CUM);

- defining pronoun: ukr. Тепер уже всі, не тільки молода, прочували лихо (CUM);

- negative pronoun: ukr. Того ранку ніхто не передчував біди. Хохуля Хомка прокинулася разом з сонцем $і$ побігла шукати щзось на сніданок, радіючи теплим промінням (Zviriata);

- personal form of the verb: ukr. Посилаю Вам своє останнє оповідання і передчуваю, щуо будете лаяти мене за нього, бо я й сам себе лаю [CUM].

According to the communicative rank such participant of the situation belongs to the Centre zone of attention. The author characterizes the Experiencer presenting such taxonomic classes:

- ANIMAL: ukr. Його наближення передуували звірі й птахи (CUM);

- PERSON: ukr. Барбаров інстинктом угадував щзось недобре й тому весь час добивався, щоб його перевели куди інде, скажімо, в одиночку (CUM);

- BODY ORGAN: ukr. Рушила підвода, а Олена услід чоловікові та сину довго $i$ сумно дивилася, наче передчувало серие ї̈, щзо станеться у Мньові (CUM);

- JOB: ukr. I все ж художник якимсь внутрішнім, якимсь «шостим» почуттям вгадує, щзо изі картини їй подобаються менше (KUM).

In the English language in the situation of "the process of irrational state acquisition" Experiencer occupies the position of subject as well: eng. Only Mr Hattersley could prophesy about the past and still get it wrong (BNC). Syntactically such participant may be expressed with:

- singular or plural noun: eng. Does Mr Bush foresee some sort of crisis during which his image will suffer unless boosted? (BNC); Dreams can foretell the future (BNC); 
- personal pronoun: eng. She guessed the answer straight away (BNC);

- defining pronoun: eng. This was not entirely a semantic shift, and was to foreshadow a much wider change in attitude to the relationship between the state and the economy, which was to be felt throughout the 1980s (BNC);

- negative pronoun: eng. Nobody felt the board members needed to know about the problem (Dien Dan).

According to the communicative rank in the English language as it was in the Ukrainian language the Experiencer belongs to the Centre. The study divides the Experiencer of this group of predicates according to such taxonomic classes:

- PERSON: eng. англ. It is often amazing how the most insignificant contributor to a project can foresee the subtlest problem and devise a solution (BNC);

- FEELING: eng. Intuition seems like a mysterious, magical thing and it may feel like it's not possible to measure or recognize as it arises (BNC);

- NATURE POWER: eng. Nature seems to portend no danger (BNC);

- IMAGE: eng. Dreams can foretell the future (BNC).

In the German language in the situation of "the process of irrational state acquisition" Experiencer occupies the position of the subject as well: ger. Eigenartige Veränderungen seines Vaters spüre er, sagte Hawa, das sei doch nicht seine Art, förmlich rachsüchtig benehme er sich (DWDS). Syntactically this participant may be expressed with:

- singular or plural noun: ger. Der Melancholiker sieht die Welt durch eine schwarze Brille, wittert überall Unheil, fühlt sich stets vom Schicksal benachteiligt und ist immer geneigt zu glauben, dass morgen die Welt untergeht (DWDS); Hier witterten die Aufklärer verständlicherweise höchste Gefahr (DWDS);

- personal pronoun: ger. Eigenartige Veränderungen seines Vaters spüre er, sagte Hawa, das sei doch nicht seine Art, förmlich rachsüchtig benehme er sich (DWDS);

- interrogative pronoun: ger. Wer hätte da noch Böses voraussehen mögen (DWDS);

- negative pronoun: ger. Am Ende seiner ausgedehnten Recherchereise kommt von Boehm zu der Erkenntnis: „,Niemand kann vorhersagen, was die Zukunft wirklich bringt“ (DWDS);

- indefinite-personal pronoun: ger. Schließlich spürt man trotz dieser Bedenken die Lust am Abenteuer, am Experiment (DWDS);

- relative pronoun: ger. Schließlich spürt man trotz dieser Bedenken die Lust am Abenteuer, am Experiment (DWDS).

According to the communicative rank Experiencer belongs to the Centre zone of attention. The paper presents such taxonomic classes of the participants:

- PERSON: ger. Plötzlich steht irgendwo ein Mann auf, nicht selten auch eine Frau, hat Gesichte und Gotteserscheinungen, wahrsagt, tut Wunder, heilt Kranke, tut Gegner in den Bann und übt eine erstaunliche Wirkung auf die Massen aus (DWDS);

- BODY ORGAN: ger. Die Seele fühlt von Anfang an: Wie pränatale Erfahrungen unsere Beziehungsfähigkeit prägen (Bettina).

In the Ukrainian language in the situation of "the process of irrational state acquisition" Stimulus occupies the position of the direct object: ukr. Вієльгорський угадував думки схвильованого автора (CUM). Syntactically this participant may be expressed with:

- singular or plural noun: ukr. Серие передчувало нешастя [КУМ]; Я вгадував думки, подіï, фрази (author's);

- substantive adjective: ukr. Я передчував недобре (author's). 
According to the communicative rank the actant Stimulus belongs to the Centre. Actant Stimulus belongs to such taxonomic classes:

- EVENT: ukr. У ті роки цей фільм був знаменням епохи - глядач вмів думати і передчувати зміни, вірити в зміни і бачити в інтелектуалах та дисидентах провісників змін (CUM);

- PERSON: ukr. У такій грі на випередження немає нічого надзвичайного Антонича у Львові передчували... (CUM).

In the English language the actant Stimulus is presented in such way: eng. Do they augur victory or defeat for the Israelites? (BNC). Syntactical role of the actant Stimulus may be presented with the direct object. Syntactically such participant may be expressed with:

- singular and plural noun: eng. They foretell events, providing a sort of rationale for the extraordinary exploits (BNC); Her appearance here would presage a shipwreck, the candle lighting the way for pall bearers who would follow (BNC);

- defining pronoun: eng. In the event, Wilson opted for the cosmetic exercise, but no one could foretell this in February 1974 (BNC);

- relative pronoun: eng. англ. One key feature of her method was to differentiate between (1) what we know; (2) what we can guess or infer... (BNC);

- subordinate noun clause: eng. Are you inferring (that) I'm not capable of doing the job? $(B N C)$.

According to the communicative rank this participant of the situation is considered as an Object that belongs to the Centre zone of attention. Actant Stimulus is also characterized with such taxonomic classes as:

- IMAGE: eng. The chief stylist at General Motors, Harvey Earl, paid a visit to an air force base where, seeing the new twin-tailed fighters, he was inspired to' intuit' the automobile shape of the future - twin tail fins (BNC);

- EVENT: eng. You're one lousy prophet, too. You couldn't even prophesy your own death, when it was standing right in front of you [BNC].

In the German language in the situation of the process of irrational state acquisition the actant Stimulus occupies the position of direct object: ger. Sie spürt ein leichtes, nicht unangenehmes Frösteln an ihrem Körper (DWDS). Syntactically such participant of the situation may be expressed with:

- singular or plural noun: ger. Wir reden, als ließe sich ein Schicksal vorausbestimmen und mit gutem Verständnis zusammenbauen (DWDS); Nach einigen Zwischenfällen entdeckt er, dass man mit dem Ring Ereignisse voraussehen und Gedanken lesen kann $(R C)$;

- personal pronoun: ger. Es wird noch einmal schneien, in diesem März, er kann es in den Knochen spüren, ein frostiges, unangenehmes Prickeln (DWDS);

- defining pronoun: ger. "Spürst du das??, fragt Hans plötzlich, “da ist Elektrizität in der Luft! Lass uns lieber umkehren” (DWDS).

According to the communicative rank the actant Stimulus belongs to the position of Object that is in the Centre zone of attention. In the German language the author outlines such taxonomic classes for the actant Stimulus:

- ВІДЧУТТЯ: нім. Du wirst es sicher gespürt haben, es ist ein ausgesprochen unangenehmes Gefühl (DWDS);

- FEELING: ger. Du wirst es sicher gespürt haben, es ist ein ausgesprochen unangenehmes Gefühl (DWDS);

- EVENT: ger. Eigenartige Veränderungen seines Vaters spüre er, sagte Hawa, das sei doch nicht seine Art, förmlich rachsüchtig benehme er sich (DWDS); 
- BORDER: ger. Diese rote Linie muß man erraten und darf sie niemals übertreten $(D W D S)$;

- IDEA: ger. Als hätte er ihre Gedanken erraten (DWDS).

The author singles out the other participant for the researched group of predicates that is presented as the actant Content. In the process of irrational state acquisition this actant occupies the position of indirect object: ukr. Мабуть, підсвідомо здогадуючись про мої почуття, мовчки курить $і$ більше не дістає розмовою (CUM). Syntactically such participant of the situation may be expressed with the subordinate noun clause: ukr. Підсвідомо я здогадувався, що ие побачення затіяно, аби вивести мене з рівноваги (CUM).

According to the communicative rank such participant is presented as a Periphery. The paper singles out such taxonomic classes for the actant Content:

- STATE OF AFFAIRS: ukr. Ніби й сам підсвідомо здогадувався про реальний стан справ в нерухомості й банках, але лише читання форуму остаточно уберегло від необдуманих покупок та подальшого тримання депозитів та гривні (Forum.Domik.Ua);

- IMAGE: ukr. Він щзе не знав, щзо иче $і$ є любов, яка повільно розгорялася у його сериі, та вже підсвідомо здогадувався, що ия пекуча ніжність надії та туга за домівкою, за спільністю зі своїм народом і радістю від зустрічі з ним стають його єством (Bonzels, 2013: 24).

In the English language in the situation of "the process of irrational state acquisition" it is singled out the participant Content that occupies the position of indirect object: eng. Can you guess what this data set is? (Translate.ru). Syntactically actant Content may be expressed with:

- subordinate noun clause: eng. Perhaps the Germans might have guessed that Normandy was the real invasion site (Translate.ru);

- subordinate adverb clause of place: eng. And so dispersed, I can 't make a guess where he lives (Translate.ru);

- subordinate adverb clause of reason: eng. Of course, it is not difficult to guess why Putin preferred Trump to his opponent, former Secretary of State Hillary Clinton (Translate.ru).

According to the communicative rank the actant Content is presented as a Periphery. The paper characterizes this participant according to the such taxonomic class:

- INFORMATION: eng. And so dispersed, I can't make a guess where he lives (Translate.ru).

In the German language in the situation of "the process of irrational state acquisition" the participant Content occupies the position of indirect object: ger. Möchte jemand raten, welche das ist? (Translate.ru). Syntactically this participant may be expressed with:

- singular or plural noun: ger. Frankreich werde überdies je ein Dutzend Seeoffiziere und Piloten aus Nicaragua ausbilden; der Rest lasse sich erraten [DWDS]; Und genau das ist der springende Punkt. Wünsche von den Lippen lesen = Wünsche erraten (Bred, 2011);

- subordinate noun clause: ger. Und raten Sie was wir in dem Angriffscode gefunden haben? (Translate.ru).

According to the communicative rank the participant Content is presented as a Periphery. The author characterizes the actant Content according to such taxonomic classes:

- INFORMATION: ger. Möchte jemand raten, welche das ist? (Translate.ru);

- BORDER: ger. Diese rote Linie muß man erraten und darf sie niemals übertreten $(D W D S)$;

- IDEA: ger. Als hätte er ihre Gedanken erraten (DWDS);

- PERSON: ger. Der Concierge einer ganzen Nation also orakelt über Ibsen (DWDS). 


\section{Analysis and conclusions}

Thus, it has been specified the notion of predicate (as a constituent that defines subject relation with other constituents of the semantic structure) and actant (the participant that fills predicate's valence according to certain semantic role). In the Ukrainian, English and German languages predicate-actant models of the thematic group of predicates to define the situation of the process of irrational state acquisition present such participants as Experiencer, Stimulus and Content. Predicate-actant relations of the researched thematic group present the phenomenon of irrationality as the one that needs a certain participant (Experincer) that is influenced (Stimulus) and "feels" (receives) some information (Content).

The prospects of the following studies dealing with irrational vocabulary concern with comparative research of specifiers of the thematic group of predicates in the Ukrainian, English and German languages.

\section{References}

Apresjan, Ju. D. (2021). Fundamental'naja klassifikacija predikatov i sistemnaja leksikografija [Fundamental classification of predicates and system lexicography]. https://iling.spb.ru/typo/ materials/gc03pdf/apresjan_spb2003.pdf(02.05.2021) [in Russian].

Bohovyk, O. A. (2016). Semantyko-syntaksychna typolohiia predykativ znannia v anhliiskii, ukrainskii ta rosiiskii movakh. Dysertatsiia na zdobuttia naukovoho stupenia kandydata filolohichnykh nauk. 10.02.17. - porivnialno-istorychne i typolohichne movoznavstvo [Semantic and syntactical typology of the knowledge predicates in the English, Ukrainian and Russian languages. Thesis for the obtaining of the degree of the Candidate of Philological Sciences. 10.02.17 - comparative and typological linguistics]. http://enpuir.npu.edu.ua/handle/123456789/12119 (02.05.2021) [in Ukrainian].

Bonzels, V. (2013). Nebesnyi narod [Sky folk]. Ternopil, Bohdan [in Ukrainian].

Valihura, H. (2009). Semantyko-syntaksychna struktura rechen z ilokutyvnymy predykatamy [Semantic and syntactical structure of the sentences with illocutionary predicates]. Naukovyi visnyk Chernivetskoho universytetu. Slovianska filolohiia, № 475-477. p. 143-147 [in Ukrainian].

Demenchuk, O. V. (2014). Dynamichni modeli pertseptyvnoi leksyky (na materiali ukrainskoi, polskoi ta anhliiskoi mov) [Dynamic models of perceptional vocabulary (basing on the Ukrainian, Polish and English languages)]. Filolohichni studii. Isuue No. 11, p. 39-46 [in Ukrainian].

Zviriata (2021). Svit kazky. http://talesworld.org.ua/taxonomy/term/1/0? page=10 (02.05.2021) [in Ukrainian].

Krasnova, L. M. (2011). Metodolohichni zasady stvorennia typolohii predykativ [Methodological fundamentals of predicates typology development]. Filolohichni nauky, p. 37-39 [in Ukrainian].

KUM (2021) - Korpus ukrainskoi movy [CUL - Corpus oft he Ukrainian language], http:// www.mova.info/corpus.aspx (02.05.2021). [in Ukrainian]

Mustajoki, A. S. (2006). Teorija funkcional'nogo sintaksisa [The theory of functional syntax]. Moskva: Jazyki slavjanskoj kul'tury [in Russian].

Nadzvychaini novyny (2021). Vybukh u Kyievi: batut, vid yakoho tilky-no vidiishly dity, zavalylo ulamkamy betonu ta metalu [Breaking news. The explosion in Kyiv: trampoline the children have just left was filled up with fragments of concrete and metal]. https://nnovosti.info/stories/ 
vibuh_u_kijevi_batut_vid_jakogo_tilki_no_vidijshli_diti_zavalilo_ulamkami_betonu_ta_met-

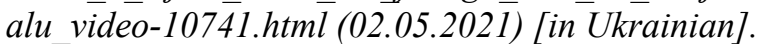

Paducheva, E. V. (2004). Dinamicheskie modeli v semantike leksiki [Dynamic models in vocabulary semantics]. Moskva: Jazyki slavjanskoj kul'tury [in Russian].

Ruzhenceva, N.B. (1991). Semanticheskie modeli predlozhenij s predikatami sozidanija [Semantic models of sentences with creation predicates]. Leksicheskaja semantika. Sverdlovsk, p. 86-93 [in Russian].

Sabitova, Z. K. (2004). Sintaksicheskie sposoby reprezentacii situacii dejstvitel'nosti [Syntactical ways to represent the real situation]. Suademos de Rusistica Espanola, № 1 [in Russian].

Smirnova, N.V., Spiridonov, D.V. (2012). Aktantno-predikatnye otnoshenija v semantike teleskopnyh leksicheskih edinic (na materiale franzuskogo jazyka) [Actant-predicate relations in the semantics of telescope lexical units (basing on the French language)]. Gumanitarnye issledovanija v Vostochnoj Sibiri i na Dal'nem Vostoke, № 2. p. 5-11. [in Russian].

CUM (2021) - Slovnyk ukrainskoi movy: v 11 t. [DUL - Disctionary of the Ukrainian language: in 11 Volumes]. Kyiv 1970-1980. [in Ukrainian]

Susov, I.P. (1973). Semanticheskaja struktura predlozhenija [Semantic structure of a sentence]. Tul'skij gosudarstvennyj pedagogicheskij institut im. L. N. Tolstogo, p. 141. [in Russian];

Shumeikina, A.V. (2009). Suchasnyi pidkhid do analizu semantychnoi struktury bahatoznachnoho slova [Modern approach to the analysis of the semantic structure of a polysemantic word].

Ridnyi krai, № 1, p. 62-68.

Shvedova, N. Ju. (2005). O sootnoshenii grammaticheskih i semanticheskih harakteristik predlozhenija [On the correlations of grammatical and semantic characteristics of a sentence]. Moskva, izdatel'stvo: Jazyki slavjanskoj kul'tury [in Russian].

Bettina, A. (2005). Die Seele fühlt von Anfang an: Wie pränatale Erfahrungen unsere Beziehungsfähigkeit prägen. Mit einem Vorwort von Ludwig Janus [The soul feels from the beginning: how prenatal experience forms our ability to relations. With a foreword of Ludwig Janus]. Kösel-Verlag [in German].

BNC (2021) - The British National Corpus https://www.english-corpora.org/bnc/ (02.05.2021) [in English].

Bred, S. (2011). Wie geht ,Wünsche von den Lippen lesen"? Der Beziehungs-Ratgeber [How do you "read wishes from your lips"? The relationship advisor] http://beziehungsblog.bred.at/ wie-geht-wunsche-von-den-lippen-lesen/ [in German].

Classes. Ru (2021). Wir spüren [We feel]. https://classes.ru/context-german-russian-term1642655.htm (02.05.2021) [in German].

Dien Dan (2021) https://diendan.hocmai.vn/threads/luyen-tap-sentence-transformationadvanced.731227/page-2/ (02.05.2021) [in English].

DWDS (2021) - Digitales Wörterbucher der Deutschen Sprache: https://www.dwds.de/ (02.05.2021) [in German].

Facebook (2021) https://www.facebook.com/kochutjewelry/photos (02.05.2021) [in English].

Forum.Domik.Ua (2021) https://forum.domik.ua/gde-dno-t259-3240.html (02.05.2021)

[in English].

Musin (2021). https://musin.zp.ua/uk/zaporozhe/theatres/gidke-kachenya

(02.05.2021) [in English].

$R C$ (2021) - Reverso Context. https://context.reverso.net/\%C3\%BCbersetzung/italienisch-deutsch/predire (02.05.2021) [in English].

Translate.ru (2021) m.traslate.ru (02.05.2021) [in German]. 